\title{
Essential Oils from Croton Species: Chemical Composition, in vitro and in silico Antileishmanial Evaluation, Antioxidant and Cytotoxicity Activities
}

\author{
Selene M. Morais, ${ }^{(*, a, b}$ Danyelle S. Cossolosso, ${ }^{a}$ Antonio A. S. Silva, ${ }^{c}$ \\ Manoel O. de Moraes Filho, ${ }^{c}$ Maria J. Teixeira,${ }^{d}$ Claudio C. Campello, ${ }^{a}$ \\ Oriel H. Bonilla, ${ }^{e}$ Valdir F. de Paula Júnior ${ }^{a}$ and Nadja S. Vila-Nova ${ }^{f}$ \\ ${ }^{a}$ Programa de Pós-Graduação em Ciências Veterinárias, Faculdade de Medicina Veterinária, \\ Universidade Estadual do Ceará, 60714-903 Fortaleza-CE, Brazil \\ ${ }^{b}$ Curso de Química, Universidade Estadual do Ceará, 60714-903 Fortaleza-CE, Brazil \\ ${ }^{c}$ Departamento de Patologia e Medicina Legal, Faculdade de Medicina, \\ Universidade Federal do Ceará, 60430-160 Fortaleza-CE, Brazil \\ ${ }^{d}$ Departamento de Fisiologia e Farmacologia, Faculdade de Medicina, \\ Universidade Federal do Ceará, 60430-160 Fortaleza-CE, Brazil \\ ${ }^{e}$ Curso de Biologia, Universidade Estadual do Ceará, 60714-903 Fortaleza-CE, Brazil \\ ${ }^{f}$ Departamento de Medicina Veterinária, Faculdades Nova Esperança, \\ 58067-698 João Pessoa-PB, Brazil
}

\begin{abstract}
Chemotherapy treatment of leishmaniasis is based on the use of pentavalent antimonials, but these drugs present low efficacy and high toxicity. In the search for new antileishmanial agents, essential oils (EOs) from four Croton species (C. argyrophylloides, C. jacobinensis, C. nepetifolius and $C$. sincorensis) were evaluated against Leishmania infantum chagasi, L. amazonensis and L. braziliensis. EOs were analyzed by gas chromatography combined with mass spectrometry. Spathulenol, $\beta$-caryophyllene, $\beta$-caryophyllene oxide, 1,8-cineole and methyl eugenol were the major constituents. The evaluation of antioxidant activity by the 1,1-diphenyl-2-picryl-hydrazyl (DPPH) method showed that all EOs have moderate antioxidant activity. All oils were similarly active against $L$. i. chagasi, and $C$. nepetifolius $\mathrm{EO}$ showed the best result against $L$. amazonensis, with median inhibitory concentrations $\left(\mathrm{IC}_{50}\right)$ of $9.87 \mu \mathrm{g} \mathrm{mL} \mathrm{m}^{-1}$, similar to amphotericin $\mathrm{B}$ $\left(\mathrm{IC}_{50}=7.38 \mu \mathrm{g} \mathrm{mL}^{-1}\right)$. The oils presented low cytotoxicity in macrophages. The in silico analysis revealed that spathulenol and 1,8-cineole were active against the enzyme Leishmania infantum trypanothione reductase ( $\mathrm{LiTR}$ ), showing excellent interaction energies, making them promising agents for leishmaniasis control.
\end{abstract}

Keywords: Euphorbiaceae, Caatinga plants, Leishmania, LiTR enzyme, computational analysis

\section{Introduction}

Leishmaniasis is a growing public health problem in many countries of the Americas, Asia, Europe and Africa. The World Health Organization ${ }^{1}$ indicates that leishmaniasis is among the six most important tropical diseases in the world. The adoption of different leishmaniasis control strategies in Brazil is part of the National Policy on Integrative and Complementary Practices of the Unified Health System (SUS). This policy is due to the continued

*e-mail: selenemaiademorais@gmail.com increase in diseases caused by these parasites, in both visceral and cutaneous forms, as well the different epidemiological situations found due to urbanization. ${ }^{2}$

Chemotherapy treatment of leishmaniasis is based on the use of pentavalent antimonials, but these drugs present low efficacy and high toxicity, leading to many side effects. Therefore, medicinal plants have been studied in the search for new antileishmanial agents. Several Brazilian medicinal plants have been assayed against promastigotes of L. amazonensis, ${ }^{3}$ and in vitro efficacy of the oil-resin of Copaifera reticulata against the promastigote forms of L. infantum chagasi has been reported. ${ }^{4}$ 
Many biological and pharmacological studies have proven the presence of active compounds in plants of the Croton genus and their activity against many diseases. Some examples are activity against human liver cancer cell lines, ${ }^{5}$ anti-inflammatory, ${ }^{6}$ antinociceptive, ${ }^{7}$ hypoglycemic, antiulcer and antiestrogen. ${ }^{8,9}$ The essential oils (EOs) of several Croton species (Euphorbiaceae) present insecticidal, ${ }^{10}$ antifungal, ${ }^{11}$ antileishmanial, ${ }^{12}$ ovine cervix relaxant, ${ }^{13}$ antibacterial and antioxidant ${ }^{14}$ properties.

Glutathione reductase (GR) is responsible for the redox defense against Leishmania in mammals, but parasites produce other detoxification enzymes to defend against oxidative harm. These are the trypanothiones [N1, N8-bis (glutathionyl) spermidine] $\left(\mathrm{TS}_{2}\right)$, synthesized by trypanothione synthase (TryS), reduced to $\mathrm{T}(\mathrm{SH})_{2}$ by trypanothione reductase (TR), and two other enzymes, tryparedoxin and tryparedoxin peroxidase I (TXN/TXNPx), which neutralize the hydrogen peroxide produced by macrophages during infection. This is an escape route, which increases the survival chances for the parasite in the parasitophorous vacuole. ${ }^{15}$ The enzymes TR and GR are involved in the direct or indirect protection of the parasite, endogenously and exogenously. ${ }^{16}$ Thus, TR enzyme is considered an attractive target for the design of antileishmanial drugs by using computational chemistry. ${ }^{17}$

Due to several biological activities of Croton EOs, four species from the Caatinga biome of northeastern Brazil were chosen for investigation of their potential as antileishmanial agents. We evaluated their chemical composition, antioxidant action, antileishmanial activities against promastigotes of Leishmania infantum chagasi, L. braziliensis and L. amazonensis, toxicity in macrophages AMJ2-C11, and performed computational analysis of essential oil constituents in relation to Leishmania infantum trypanothione reductase ( $L i T R$ ).

\section{Experimental}

\section{Plant material and extraction of essential oils}

Leaves of Croton species were collected in the medicinal plant garden of the Biology Department of Ceará State University, Fortaleza, Ceará, Brazil (347'335" South latitude; $38^{\circ} 33^{\prime} 328^{\prime \prime}$ West longitude). Specimens of the Croton species were deposited in the Prisco Bezerra Herbarium of Ceará Federal University under numbers 46715, 46716, 46719, and 46720 for C. argyrophylloides Muell. Arg., C. jacobinensis Baill., C. nepetifolius Baill., and $C$. sincorensis Mart., respectively.

The essential oils were extracted from fresh plant leaves by hydrodistillation using a Clevenger apparatus, ${ }^{18}$ where $300 \mathrm{~g}$ of leaves was placed in a $5 \mathrm{~L}$ round-bottom flask placed on a heating mantle containing $2,000 \mathrm{~mL}$ of water. The flask was connected to a glass oil separator, in turn connected to a condenser. After $3 \mathrm{~h}$ of heating, the EOs were collected and dried over anhydrous $\mathrm{Na}_{2} \mathrm{SO}_{4}$ (ca. $1 \mathrm{~g}$ ) and preserved in sealed vials at $4{ }^{\circ} \mathrm{C}$ prior to gas chromatography-mass spectrometry (GC-MS) analysis. The oils presented yields of 0.2 to $3 \%(\mathrm{~m} / \mathrm{m})$.

\section{GC-MS analysis}

The chemical analysis of the essential oils constituents was performed with a Shimadzu QP-2010 instrument, employing the following conditions: column: DB-5ms (Agilent, part No. 122-5532) coated fused silica capillary column $(30 \mathrm{~m} \times 0.25 \mathrm{~mm} \times 0.25 \mu \mathrm{m})$; carrier gas: $\mathrm{He}$ (1 $\mathrm{mL} \mathrm{min}^{-1}$, in constant linear velocity mode); injector temperature of $250{ }^{\circ} \mathrm{C}$ in split mode (1:100); and detector temperature of $250{ }^{\circ} \mathrm{C}$. The column temperature programming was 35 to $180^{\circ} \mathrm{C}$ at $4{ }^{\circ} \mathrm{C} \mathrm{min}^{-1}$ then 180 to $280^{\circ} \mathrm{C}$ at $17^{\circ} \mathrm{C} \mathrm{min}{ }^{-1}$, remaining at $280^{\circ} \mathrm{C}$ for $10 \mathrm{~min}$. Mass spectra were obtained by electron impact of $70 \mathrm{eV}$. The volume of sample injected was $1 \mu \mathrm{L}$. The components were identified from their Kovats indexes, calculated by linear regression interpolation relative to $\mathrm{GC}$ retention times of main compounds and by comparison of their mass spectra with those present in the computer data bank (NIST) and published literature. ${ }^{19}$

\section{Antioxidant assay}

The antioxidant activity was determined using the 1,1-diphenyl-2-picryl-hydrazyl (DPPH) method, according to Yepez et al..$^{20} \mathrm{In}$ a test tube, $3.9 \mathrm{~mL}$ of a $6.5 \times 10^{-5} \mathrm{M}$ methanol solution of DPPH was mixed with $0.1 \mathrm{~mL}$ of an EO methanol solution. After 60 min, the absorbance was read with a spectrophotometer at $515 \mathrm{~nm}$ at concentrations of $10,000,5,000,1,000,500,100,50,10$ and $5 \mathrm{ppm}$ of the samples. The inhibition percentage (IP) was calculated in relation to initial DPPH solution UV absorption by the equation: $\mathrm{IP}(\%)=\left[\left(\mathrm{Abs}_{\mathrm{DPPH}}-\mathrm{Abs}_{\mathrm{SAMPLE}}\right) / \mathrm{Abs}_{\mathrm{DPPH}}\right] \times 100$. Linear regression analysis of the inhibition percentage of the various concentrations was used to find a linear equation to obtain the $\mathrm{IC}_{50}$, the effective concentration of the sample that inhibits $50 \%$ of the radical DPPH.

\section{Cytotoxicity assay}

The macrophage lineage AMJ2-C11 was seeded at a concentration of $4 \times 10^{4}$ cells well $^{-1}$ in 96-well plates and then incubated at $37^{\circ} \mathrm{C}$ for $24 \mathrm{~h}$ in a humidified incubator 
in $5 \% \mathrm{CO}_{2}$. The EOs were tested at a concentration of $100 \mathrm{mg} \mathrm{mL}^{-1}$ and amphotericin B was used as control. The viability of the macrophages was determined using the 3-[4,5-dimethylthiazol-2-yl] 2,5-diphenyltetrazolium bromide (MTT) assay as described below. The number of living promastigotes was indirectly determined by the optical density (OD, $620 \mathrm{~nm}$ ), representing the survival percentage. ${ }^{21}$

\section{Leishmanicidal assay}

The parasites Leishmania (L.) chagasi (strain LVHSI17), Leishmania (L.) amazonensis (strain BA336) and Leishmania (V.) braziliensis (strain LTCP393) were cultured in Grace medium supplemented with $10 \%$ fetal serum and 5\% human male urine and maintained at $26{ }^{\circ} \mathrm{C}$. Then the cultures were examined under a light microscope to confirm the viability of the parasites. For the in vitro tests against promastigotes in 96-well plates, promastigotes were added at a concentration of $10^{6}$ cells well ${ }^{-1}$, determined by counting in a Neubauer chamber. The oils were placed at concentrations of 100 , $50,25,12.5$ and $6.25 \mathrm{mg} \mathrm{mL}^{-1}$, and amphotericin $\mathrm{B}$ was chosen as the control drug. The plates were incubated for $24 \mathrm{~h}$ at $24{ }^{\circ} \mathrm{C}$. Assays were performed in duplicate with one replicate of each test. Cell viability was assayed using colorimetric MTT $\left(\right.$ Sigma $\left.^{\circledR}\right)$. MTT $\left(5 \mathrm{mg} \mathrm{mL}^{-1}\right)$ was dissolved in PBS (phosphate buffered saline) and passed through a sterile membrane with pore size of $0.22 \mathrm{~m}$, and $20 \mu \mathrm{L}$ well ${ }^{-1}$ was added. The wells were read after $4 \mathrm{~h}$ at $24{ }^{\circ} \mathrm{C}$. For cell lysis and solubilization of the formazan crystals, a solution of 50\% SDS (sodium dodecyl sulfate) and 10 to $50 \%$ isopropyl alcohol was added $\left(100 \mu \mathrm{L}\right.$ well $\left.{ }^{-1}\right)$. OD was determined after 15 min using a Multiskan MS microplate reader (Uniscience) at $595 \mathrm{~nm} .{ }^{22}$

\section{Computational analysis}

\section{Target protein editing}

The structure of the enzyme $L$. infantum trypanothione reductase ( $L i T R$ ) (PDB ID 6ER5) was submitted to refinement with the editing of Kollman charges, ${ }^{23}$ polar hydrogen additions and subtraction of water molecules, using AutoDockTools. ${ }^{24}$

\section{Preparation of compounds}

The chemical structures of 1,8-cineole and spathulenol were drawn in the ChemSketch freeware program. ${ }^{25}$ With the compounds' 2D chemical structure, we optimized the geometric structure by converting to a $3 \mathrm{D}$ structure and determined the molecular mass, density and molar refractivity, and exported the ligand archives in PDB format.
Then the ligands were submitted to refining by calculation of the Gasteiger charges ${ }^{26}$ with AutoDockTools 1.5.6. ${ }^{24}$

\section{Molecular docking}

The simulation was performed with AutoDock 4.2.24 The assay parameter was the Lamarckian genetic algorithm (GA), ${ }^{27}$ with the following conditions: population amount, 150; maximum number of evals, 2500000; with maximum number of generation, 27000; gene mutation rate of 0.02 ; crossover rate of 0.8 ; variance of the Cauchy distribution of the genetic mutation of $1.0,{ }^{24}$ with 100 executions. The induced coupling geometric region was determined with AutoDockTools 1.5.6, ${ }^{24}$ and the enzyme LiTR was tested using the coordinates $x:-2.70, y:-34.83, z: 16.88$, including the active site residues (Tyr221; Gly197; Asn254; Arg222; Arg228; Arg235). During the molecular docking, the following interactions were evaluated ( $\Delta$ Gbinding $=\Delta$ GvdW $+\Delta$ Gelec $+\Delta$ Ghbond $+\Delta$ Gdesolv + $\Delta$ Gtors) by molecular mechanics (MM) in AutoDock4. ${ }^{24}$

The molecular binding was conducted with the protein in the rigid state and the compounds in the flexible form to increase the precision of the angles to determine orientation and position. ${ }^{28}$

\section{Evaluation of drug-protein interactions}

After obtaining the molecular binding (receptor-ligand), the poses with lowest free energy bonds $\left(\mathrm{kcal} \mathrm{mol}^{-1}\right)^{29}$ were selected for calculation of the inhibition constants (Ki), using AutoDockTools 1.5.6. ${ }^{24}$ The interaction force of the ligand with the receptor was observed by the Accelrys Discovery Studio Visualizer 4.5, ${ }^{30}$ and the PyMOL 2.0 program $^{31}$ was used to calculate the root mean square deviation (RMSD).

\section{Statistical analysis}

The $\mathrm{IC}_{50}$ (inhibitory concentration which inhibits 50\% of Leishmania promastigotes) values were calculated from linear regression curves using the statistical software Graph Pad Prism 4.0. ${ }^{32}$ The data were initially submitted to the Shapiro-Wilk and Bartlett tests for confirmation of normal distribution and homogeneity of variance between treatments, respectively. The percentages obtained after treatments were presented as mean \pm standard deviation and analyzed by the Chi-square test at a confidence interval of $95 \%$. The data on antileishmanial activity were submitted to analysis of variance (ANOVA) and confirmed by the Shapiro-Wilk test. The homogeneity of variance among treatments was confirmed by the Bartlett test. ANOVA was performed using the GLM procedure of SAS (2002), ${ }^{33}$ and the Tukey's test was used to compare the means. 


\section{Results and Discussion}

The production of secondary metabolites in plants is related to intrinsic factors such as genetics and morphology, as well as extrinsic factors like relative humidity, wind regime, soil moisture, geographical variations, stage of the vegetative cycle, cultivation techniques and seasonal variations. ${ }^{34}$ Thus, it is important to determine the chemical composition of the essential oil of a plant each time it is collected in different conditions or places.

Table 1 shows the chemical composition of the EOs analyzed by GC-MS. The analysis showed two types of Croton species, three rich in spathulenol and caryophyllene oxide and one, $C$. nepetifolius, with major components methyl eugenol, $\beta$-caryophyllene and 1,8-cineole. Spathulenol was found in concentrations ranging from 42.54 to $7.56 \%$, and caryophyllene oxide yields varied from 68.62 to $21.76 \%$. 1,8-Cineole was the third most prevalent constituent, present in two of four essential oils. The EO composition of some Croton species, including C. argyrophylloides, can vary along the day. The main components were $\alpha$-pinene, $\beta$-caryophyllene, 1,8 -cineole, spathulenol, and caryophyllene oxide, corroborating previous reports. ${ }^{35}$
The values of antioxidant activities, expressed by median inhibitory concentrations $\left(\mathrm{IC}_{50}\right)$, of the studied EOs are shown in Table 2. The species that showed the highest antioxidant activity were $C$. argyrophylloides, C. jacobinensis and C. nepetifolius with $\mathrm{IC}_{50}$ values of $12.55,22.11$ and $24.96 \mu \mathrm{g} \mathrm{mL}^{-1}$, respectively. All Croton species showed lower antioxidant activity in relation to the standard thymol $\left(\mathrm{IC}_{50}=3.47 \mu \mathrm{g} \mathrm{mL} \mathrm{L}^{-1}\right)$ or butylated hydroxytoluene $\left(\mathrm{BHT}, \mathrm{IC}_{50}=5.16 \mu \mathrm{g} \mathrm{m}^{-1}\right.$ ). In general, phenolic compounds possess the highest antioxidant activity, monoterpene hydrocarbons, such as terpinolene, $\alpha$ - and $\gamma$-terpinene with allylic hydrogens, showed significant protective action, and allylic alcohols also presented appreciable activity. ${ }^{36}$ The Croton essential oils did not contain phenolic compounds which is the main cause of the lower antioxidant activity than the phenolic compound thymol and the commercial antioxidant BHT. Thus, spathulenol, caryophyllene, caryophyllene oxide, germacrene and other compounds with minor yields, which contain allylic hydrogens, might have contributed to the antioxidant action. The antioxidant, anti-inflammatory, antiproliferative and antimycobacterial properties of the essential oil of Psidium guineense and spathulenol were demonstrated, ${ }^{37}$ confirming the importance of this

Table 1. Relative percent composition of Croton species essential oils (EOs) by gas chromatography-mass spectrometry (GC-MS) analysis

\begin{tabular}{|c|c|c|c|c|c|c|}
\hline Constituent & $\mathrm{KI}^{19}$ & KI & C. $\arg$ & C. jac & C. nep & C. $\sin$ \\
\hline$\beta$-Pinene & 979 & 970 & - & - & - & 3.09 \\
\hline 1,8-Cineole & 1031 & 1033 & - & - & 10.44 & 5.15 \\
\hline$\alpha$-Terpineol & 1188 & 1167 & - & - & 3.58 & - \\
\hline 3,5-Dimethoxytoluene & 1264 & 1260 & - & - & 5.74 & - \\
\hline$\beta$-Elemene & 1390 & 1396 & 7.88 & - & - & - \\
\hline Methyl eugenol & 1403 & 1404 & - & - & 33.89 & - \\
\hline E-Caryophyllene & 1419 & 1426 & - & - & 21.23 & - \\
\hline$\alpha$-Humulene & 1454 & 1453 & - & - & 2.14 & - \\
\hline Alloaromadendrene & 1460 & 1454 & 3.8 & - & - & - \\
\hline Hedicariol & 1548 & 1542 & - & - & - & 7.0 \\
\hline Germacrene B & 1561 & 1562 & - & 7.61 & 5.81 & - \\
\hline Spathulenol & 1578 & 1575 & 42.54 & 15.41 & - & 9.58 \\
\hline Caryophyllene oxide & 1583 & 1583 & 40.95 & 68.62 & - & 21.76 \\
\hline Globulol & 1590 & 1585 & - & - & - & 6.36 \\
\hline Viridiflorol & 1592 & 1590 & - & - & - & 5.46 \\
\hline Humulene II epoxide & 1608 & 1606 & - & - & - & 5.63 \\
\hline 10-epi-Y-Eudesmol & 1623 & 1613 & - & - & - & 4.71 \\
\hline$\beta$-Eudesmol & 1650 & 1655 & - & - & - & 17.42 \\
\hline Total & & & 95.17 & 91.64 & 82.83 & 86.16 \\
\hline
\end{tabular}

Kovats indexes (KI) were estimated by linear regression of retention times of main compounds in the chromatograms and respective Kovats index from the literature. ${ }^{19}$ C. arg: C. argyrophylloides; C. jac: C. jacobinensis; C. nep: C. nepetifolius; C. sin: C. sincorensis. 
sesquiterpene alcohol in the activities of the Croton essential oils. $\beta$-Caryophyllene was considered an effective inhibitor of lipid peroxidation, probably due to its free radical-scavenging activity against hydroxyl radicals, superoxide anions and lipid peroxides. The mechanisms by which caryophyllene prevents liver fibrosis may be related, at least in part, to its antioxidant activity. ${ }^{38} 1,8$-Cineole was reported as an important ulcer healing agent, with the involvement of antioxidant and cytoprotective mechanisms in its gastroprotective effect. ${ }^{39}$ The EO of $C$. sincorensis displayed less antioxidant activity than other oils, probably due to lower content of stronger antioxidant compounds, such as the sesquiterpenes spathulenol and caryophyllene oxide.

Table 2. Antioxidant activity of Croton essential oils by 1,1-diphenyl2-picryl-hydrazyl (DPPH) method

\begin{tabular}{lc}
\hline EO of Croton species & $\mathrm{IC}_{50} \pm \mathrm{SD} /\left(\mu \mathrm{g} \mathrm{mL}^{-1}\right)$ \\
\hline C. argyrophylloides & $12.55 \pm 0.43$ \\
C. jacobinensis & $22.11 \pm 3.24$ \\
C. nepetifolius & $24.96 \pm 6.87$ \\
C. sincorensis & $80.59 \pm 18.98$ \\
Thymol $^{\mathrm{a}}$ & $3.47 \pm 0.09$ \\
BHT $^{\mathrm{b}}$ & $5.16 \pm 0.06$ \\
\hline
\end{tabular}

${ }^{a}$ Natural phenol common in plant essential oils; 'butylated hydroxytoluene, a standard synthetic antioxidant. $\mathrm{IC}_{50}$ : median inhibitory concentration; SD: standard deviation.

Punica granatum juice treatment by oral administration significantly reduced the average size of cutaneous leishmaniasis lesions compared with that of untreated mice, and antileishmanial activity of $P$. granatum was associated with enhanced endogenous antioxidant enzyme activities. ${ }^{40}$

Ethanol and hexane extracts of 16 Brazilian medicinal plants were tested against stationary-phase promastigotes of L. amazonensis. This in vitro assay showed six potent extracts, with $\mathrm{IC}_{50}$ values varying from 0.08 to $44.10 \mu \mathrm{gLL}^{-1}{ }^{3}$ Another study reported the in vitro efficacy of Coriandrum sativum and Lippia sidoides essential oils and Copaifera reticulata resin oil against Leishmania chagasi. The results showed that the resin oil of $C$. reticulata was the most effective against promastigotes $\left(\mathrm{IC}_{50}\right.$ of $7.88 \mu \mathrm{g} \mathrm{mL}^{-1}$ ) and amastigotes $\left(\mathrm{IC}_{50}\right.$ of $\left.0.52 \mu \mathrm{g} \mathrm{mL}^{-1}\right)$. These results were close to the pentamidine control, with $\mathrm{IC}_{50}$ of $2.149 \mu \mathrm{g} \mathrm{mL}-1$ in the test against promastigotes, and amphotericin $\mathrm{B}$ with $\mathrm{IC}_{50}$ of $9.754 \mu \mathrm{g} \mathrm{mL}{ }^{-1}$ in the amastigote forms. ${ }^{4}$

Table 3 shows the leishmanicidal assay results against promastigotes of $L$. i. chagasi, L. braziliensis and L. amazonensis, and the statistical comparison among treatments. The values of the action of EOs on Leishmania strains showed normal distribution (confirmed by the Shapiro-Wilk test) and homogeneity of variances among treatments (confirmed by Bartlett's test). All EOs studied in this work showed activity against the species $L$. i. chagasi, with no statistical differences. The $C$. nepetifolius $\mathrm{EO}$ proved to be the most active against $L$. amazonensis and L. braziliensis, followed by $C$. argyrophylloides EO. The EOs of $C$. jacobinensis and $C$. sincorensis did not differ statistically, with $\mathrm{IC}_{50}$ values of 23.79 and $27.03 \mu \mathrm{g} \mathrm{mL}^{-1}$, respectively, against $L$. amazonensis. The major compounds from the Croton species might be responsible for their bioactivities.

The EOs from C. nepetifolius and C. sincorensis showed the best results against $L$. braziliensis, with $\mathrm{IC}_{50}$ values of 9.08 and $14.16 \mu \mathrm{g} \mathrm{mL}^{-1}$, respectively, and no statistical differences between them. Thus, the antileishmanial activity of Croton essential oils can be considered relevant by comparison with the standard drug and with previous reports of antileishmanial plant products.

Figure 1 shows the results of the cytotoxicity test of the EOs against the monocytic cell line with AMJ2-C11. The results of the control drug and EOs were similar at $100 \mu \mathrm{gLL}^{-1}$ (except C. argyrophylloides, whose percentage of toxicity was much lower than the drug). The EO of C. nepetifolius at $100 \mu \mathrm{g} \mathrm{mL}^{-1}$ showed toxicity against macrophages of $44.17 \%$, statistically similar to the standard drug with $47.70 \%$ at the same concentration. These data

Table 3. Different susceptibilities of several Croton essential oils (EOs) against three types of Leishmania strains

\begin{tabular}{lccc}
\hline \multirow{2}{*}{ EO of Croton species } & \multicolumn{3}{c}{$\mathrm{IC}_{50} / \%$} \\
\cline { 2 - 4 } & L. amazonensis & L. braziliensis & L. i. chagasi \\
\hline C. argyrophylloides & $15.50 \pm 2.48 \mathrm{Ab}$ & $16.71 \pm 1.35 \mathrm{Ab}$ & $16.41 \pm 1.98 \mathrm{Aa}$ \\
C. jacobinensis & $23.79 \pm 2.11 \mathrm{Aa}$ & $22.06 \pm 4.98 \mathrm{Aa}$ & $17.69 \pm 1.19 \mathrm{Aa}$ \\
C. nepetifolius & $9.87 \pm 2.21 \mathrm{Bc}$ & $9.08 \pm 2.59 \mathrm{Bc}$ & $14.80 \pm 3.34 \mathrm{Aa}$ \\
C. sincorensis & $27.03 \pm 1.61 \mathrm{Aa}$ & $14.16 \pm 3.49 \mathrm{Bbc}$ & $13.05 \pm 3.60 \mathrm{Ba}$ \\
Amphotericin B & $7.38 \pm 1.26 \mathrm{Ac}$ & $2.50 \pm 0.54 \mathrm{Bd}$ & $5.39 \pm 1.14 \mathrm{Ab}$ \\
\hline
\end{tabular}

$\mathrm{IC}_{50}$ : median inhibitory concentration against Leishmania promastigotes. Different uppercase letters denote significant differences between columns. Different lowercase letters denote significant differences between rows. 
demonstrate the low toxicity of the four Croton essential oils. The therapeutic potential of Croton EOs, besides the low toxicity, allows these oils to be used as adjuvants in leishmaniasis treatment.

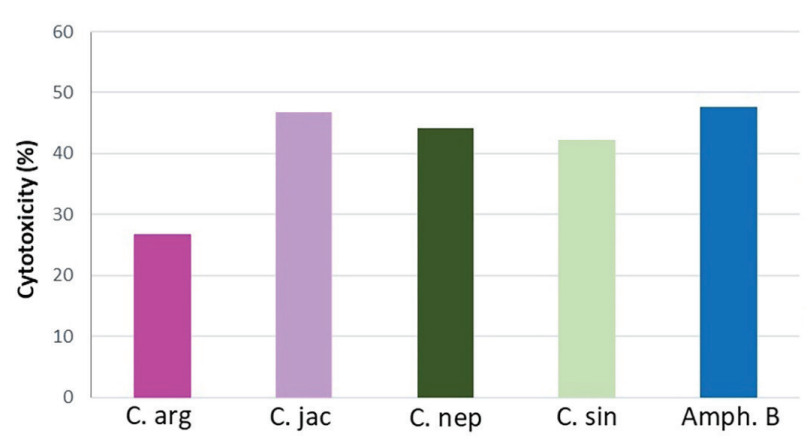

Figure 1. Cytotoxicity of Croton essential oils at the concentration of $100 \mu \mathrm{g} \mathrm{mL} \mathrm{m}^{-1}$ against monocytic cells AMJ2-C11. C. arg.: Croton argyrophylloides; $\mathrm{C}$. jac: $C$. jacobinensis; C. nep: C. nepetifolius; C. $\sin$ : C. sincorensis; Amph. B: amphotericin B.

All essential oils showed antileishmanial activity, and the most frequent compounds present in higher yields were spathulenol, caryophyllene oxide and 1,8-cineole. In this work, we tried to find new antileishmanial agents and performed computational analysis to test their action in a Leishmania infantum chagasi enzyme. The antileishmanial activity of some major compounds found in Croton oils is already known. $\beta$-Caryophyllene, found in copaiba oil, exerts activity against $L$. amazonensis, ${ }^{41}$ and it was more effective when compared to eugenol, inhibiting the growth of parasites and thus constituting a proven alternative against Trypanosoma cruzi and Leishmania brasiliensis..$^{42}$ Methyl eugenol was found in greater amounts in C. nepetifolius $\mathrm{EO}$, which showed good activity against Leishmania strains. This compound has demonstrated biological activities in previews works, such as antinociceptive and anesthetic effects in peripheral $\mathrm{Na}^{+}$channels, ${ }^{43}$ and leishmanicidal activity against several strains of Leishmania. ${ }^{44}$ Caryophyllene oxide exerts action on mitochondrial functions in Leishmania tarentolae promastigotes $(L t \mathrm{P})$ and was able to partially inhibit the leishmanial electron transport chain. ${ }^{45}$

The immunomodulatory activity of spathulenol present in Salvia mirzayanii ${ }^{46}$ is an important characteristic for antileishmanial action. Several clinical trials have established potent anti-inflammatory activity of 1,8-cineole, which suggests its use as a primary treatment or as adjunct therapy with current anti-inflammatory agents. ${ }^{47}$

Taking into account the activities of the constituents present in high yields in Croton essential oils, not yet reported as having antileishmanial activity, the compounds 1,8-cineol and spathulenol (Figure 2) were chosen to perform computational analysis in relation to the enzyme Leishmania infantum TR.
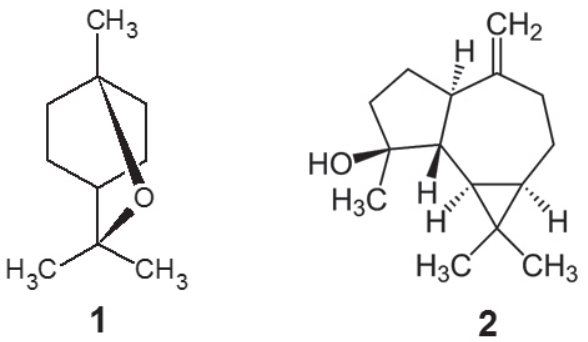

Figure 2. Representation of chemical structures of 1,8-cineole (1) and spathulenol (2) used in the molecular docking.

In the structural representation of $L i T R$ coupled to 1,8-cineole, favorable interactions of different types were formed, such as Van der Waals, hydrophobic and hydrogen bonds, with participation of 7 residues (Gly197; Ile285; Ala284; Gly195; Gly196; Tyr221; Arg222), and the ligand established $\mathrm{H}$-bonding interaction with Gly196 in a radius of $3.68 \AA$ (Figure 3).

The high complementary action of 1,8-cineole and spathulenol with $L i T R$ corroborates the findings of Turcano et al. ${ }^{17}$ They demonstrated the TR inhibition of the compound 2-(diethylamino)ethyl,4-((3-(4-nitrophenyl)3-oxopropyl)amino)benzoate with the participation of the residues Tyr221, Gly197, Asn254, Arg222 and Arg228. The residues are electrostatically linked to Arg235 (with distance of NH1 $(\operatorname{Arg} 235)-\mathrm{NH} 2(\operatorname{Arg} 228)=3.5 \AA)$. Hence, these residues are essential for the inactivation of LiTR. Our findings demonstrate that 1,8-cineole interacted with three residues (Gly 197; Tyr221; Arg222) and spathulenol interacted with four residues (Gly197; Arg222; Asn254; Tyr221), strongly indicating their use for in vitro assays.

Spathulenol established interaction of the Van der Waals, hydrophobic and H-bonding types with participation of 11 residues (Ala284; Gly197; Gly286; Ile285; Gly195; Gly196; Arg222; Asn254; Lys220; Va194; Tyr221). The interaction of hydrogen with the ligand showed a radius of $4.44 \AA$ (Figure 4).

Table 4 shows the interaction energies and the inhibition constants calculated by AutoDockTools 1.5.6. ${ }^{24}$ In these results, spathulenol showed better values, with free binding energy $\left(-4.82 \mathrm{kcal} \mathrm{mol}^{-1}\right)$ and an inhibition constant with theoretical value calculated at $294.76 \mu \mathrm{M}$, whereas 1,8-cineole has free binding energy $\left(-5.05 \mathrm{kcal} \mathrm{mol}^{-1}\right)$ and inhibition constant with a theoretical value calculated of $200.37 \mu \mathrm{M}$. Both compounds displayed good performance against $L i T R$, as shown by their excellent interaction energies and inhibition constants compared to the compounds apigenin $\left(-9.3 \mathrm{kcal} \mathrm{mol}^{-1}\right)$ and rosmarinic acid $\left(-6.5 \mathrm{kcal} \mathrm{mol}^{-1}\right)$ against the enzyme MurE, which were considered excellent inhibitors. ${ }^{48}$ 

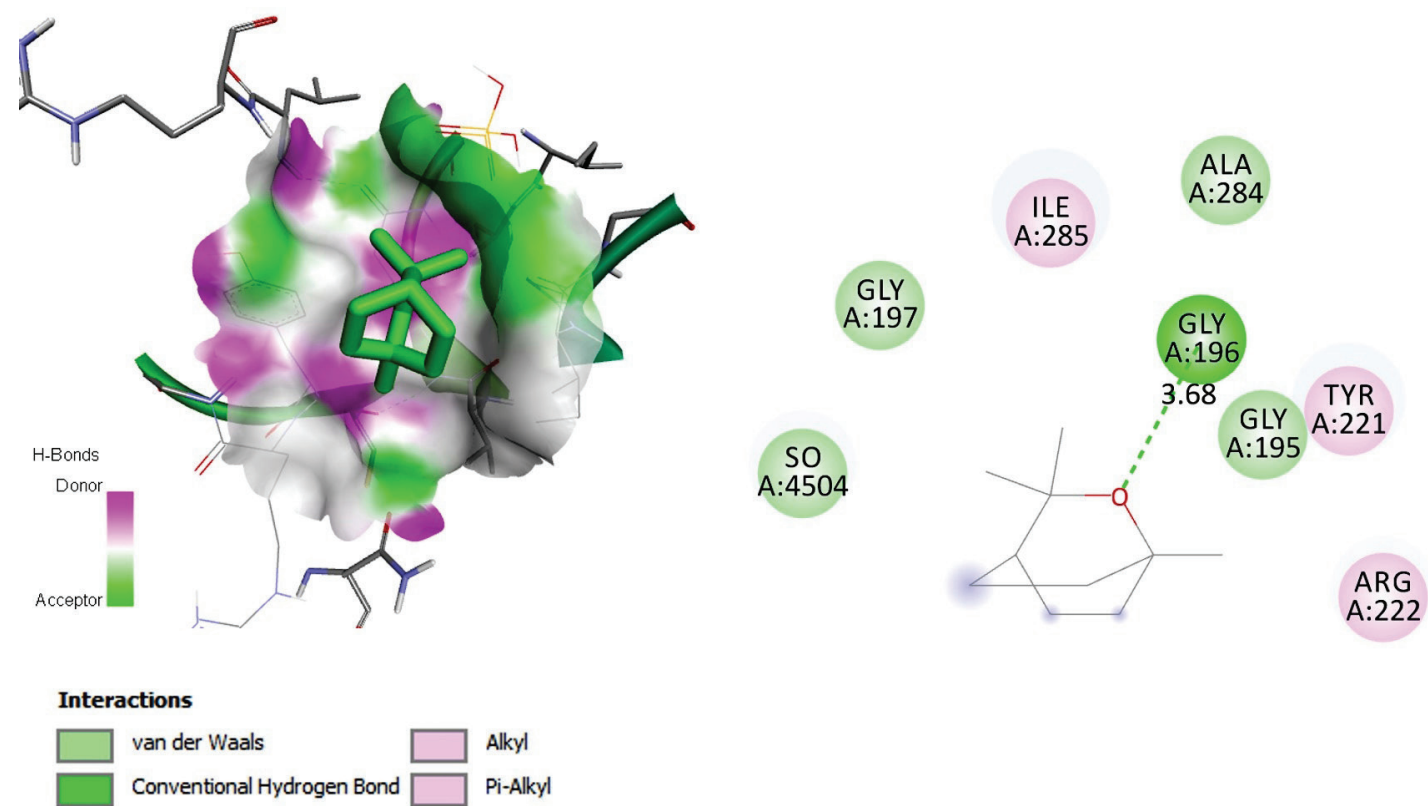

Figure 3. Interaction between 1,8-cineole and the $L i$ TR, characterizing the amino acid residues of the catalytic site involved in the complex stabilization.

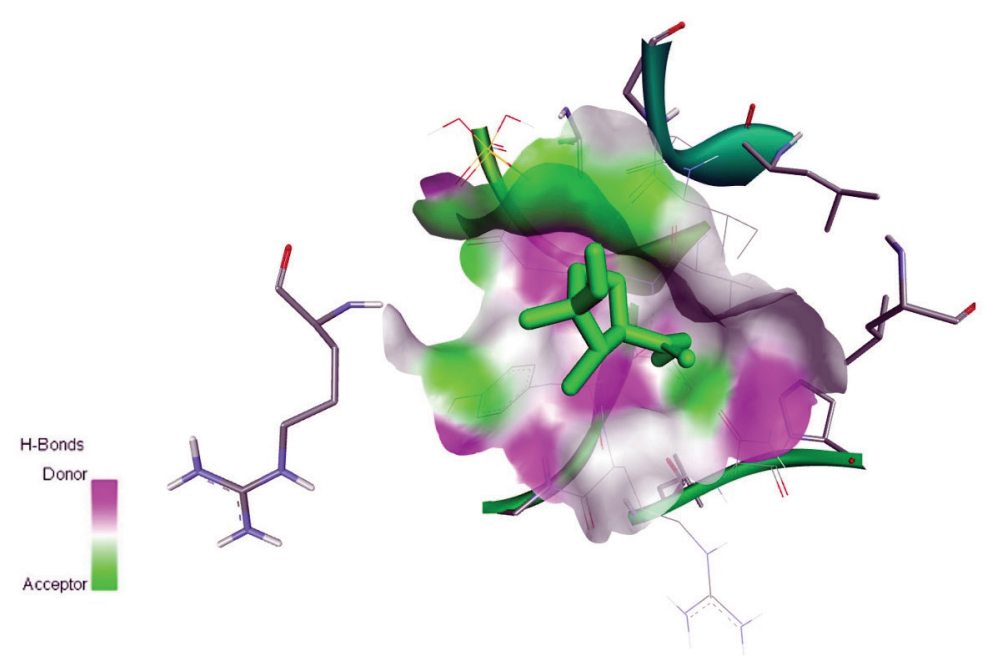

Interactions
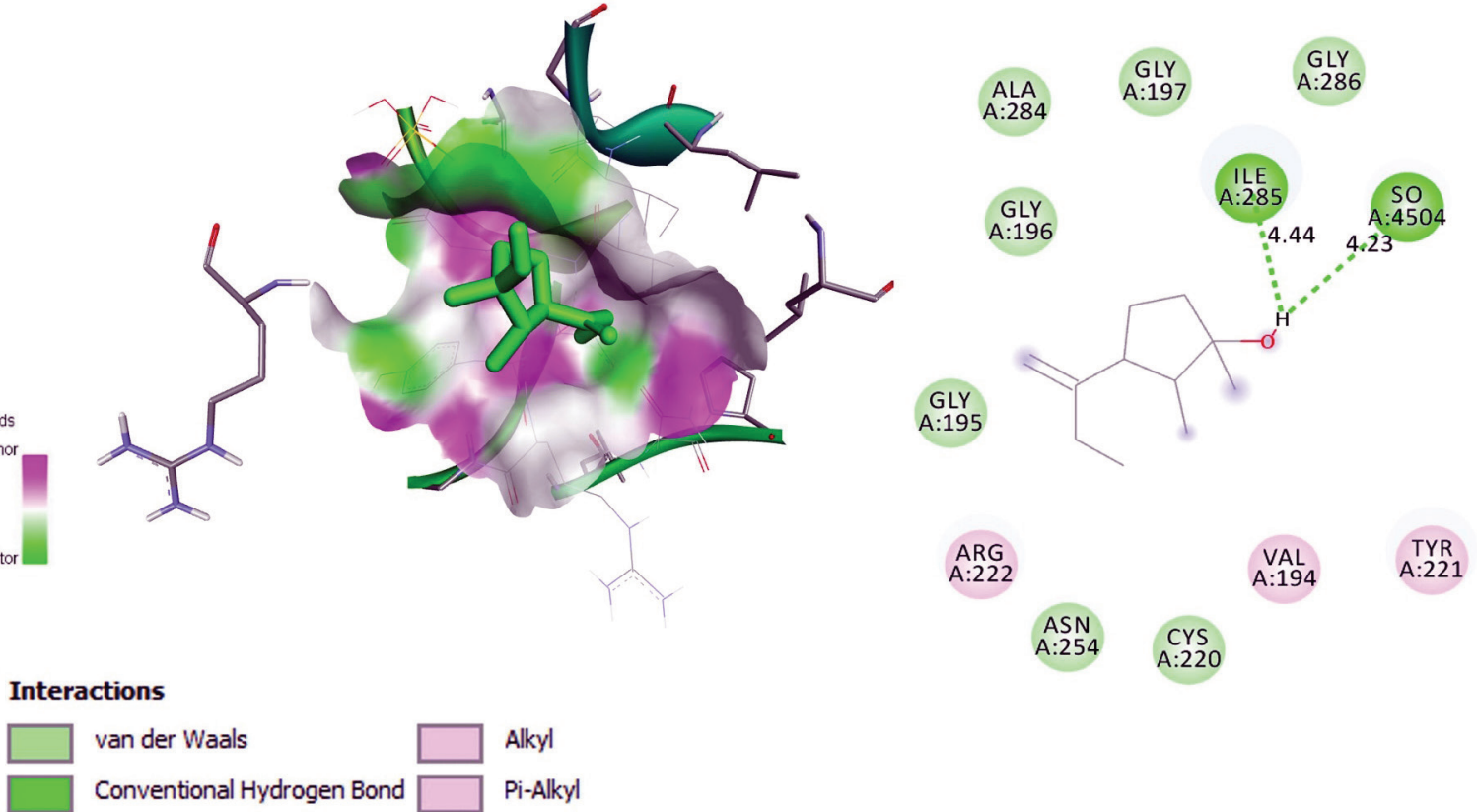

Figure 4. Representative model of molecular binding of spathulenol to LiTR and characterizing the amino acid residues of the catalytic site involved in the complex stabilization.

Table 4. Energy of interaction between spathulenol and 1,8-cineole from docking with molecular target protein $L i$ TR by molecular docking

\begin{tabular}{lcc}
\hline Parameter & Compound & Protein LiTR \\
\hline Interaction energy $(\Delta \mathrm{G}) /\left(\mathrm{kcal} \mathrm{mol}^{-1}\right)$ & 1,8 -cineole & -5.05 \\
& spathulenol & -4.82 \\
\hline \multirow{2}{*}{ Inhibition constant $(\mathrm{Ki}) / \mu \mathrm{M}$} & 1,8 -cineole & 200.37 \\
& spathulenol & 294.76 \\
\hline
\end{tabular}

LiTR: Leishmania infantum trypanothione reductase (PDB ID 6ER5).

\section{Conclusions}

This study is innovative in the search for new sources of leishmanicidal compounds using the EOs of Croton species from Brazil. The findings can support future research on EOs of these Croton species and their major components for in vivo studies. The computational evaluation of pharmacodynamics showed that the compounds 1,8-cineole and spathulenol have high affinity for the catalytic site of the enzyme LiTR, suggesting a possible mechanism 
of action. However, computational analysis of the other Croton species' constituents is recommended as well as in vitro inhibition analysis of the enzyme $L$. infantum trypanothione reductase.

\section{Acknowledgments}

We thank the Brazilian government agencies CAPES, CNPq (Universal Project, process No. 421445/2016-5) and FUNCAP for financial support.

\section{References}

1. https://www.who.int/leishmaniasis/burden/en/, accessed on January 22, 2019.

2. Ministério da Saúde; Secretaria de Vigilância em Saúde; Departamento de Vigilância Epidemiológica; Manual de Vigilância e Controle da Leishmaniose Visceral; Editora do Ministério da Saúde: Brasília, 2006.

3. Ribeiro, T. G.; Chávez-Fumagalli, M. A.; Valadares, D. G.; Franca, J. R.; Lage, P. S.; Duarte, M. C.; Andrade, P. H.; Martins, V. T.; Costa, L. E.; Arruda, A. L.; Faraco, A. A.; Coelho, E. A.; Castilho, R. O.; Exp. Parasitol. 2014, 143, 60.

4. Rondon, F. C. M.; Bevilaqua, C. M. L.; Accioly, M. P.; Morais, S. M.; Andrade-Júnior, H. F.; Carvalho, C. A.; Lima, J. C.; Magalhães, H. C. R.; Rev. Bras. Parasitol. Vet. 2012, 21, 185.

5. Pham, M. Q.; Iscache, A. L.; Pham, Q. L.; Gairin, J. E.; Fundam. Clin. Pharmacol. 2016, 30, 137; Zhao, J.; Fang, F.; Yu, L.; Wang, G.; Yang, L.; J. Ethnopharmacol. 2012, 142, 367.

6. Abdon, A. P. V.; Leal-Cardoso, J. H.; Coelho-de-Souza, A. N.; Morais, S. M.; Santos, C. F.; Braz. J. Med. Biol. Res. 2002, 35, 1215.

7. Maciel, M. A. M.; Pinto, A. C.; Arruda, A. C.; Pamplona, S. G. S. R.; Vanderlinde, F. A.; Lapa, A. J.; Echevarria, A.; Grynberg, N. F.; Colus, I. M. S.; Farias, R. A. F.; Costa, A. M. L.; Rao, V. S. N.; J. Ethnopharmacol. 2000, 70, 41.

8. Salatino, A.; Salatino, M. L. F.; Negri, G.; J. Braz. Chem. Soc. 2007, 18, 11.

9. Morais, S. M.; Cavalcanti, E. S. B.; Bertini, L. M.; Oliveira, C. L. L.; Rodrigues, J. R. B.; Cardoso, J. H. L.; J. Am. Mosq. Control Assoc. 2006, 22, 41.

10. Fontenelle, R. O. S.; Morais, S. M.; Brito, E. H. S.; Brilhante, R. S. N.; Cordeiro, R.A.; Nascimento, N. R. F.; Kerntopf, M. R.; Sidrim, J. J. C.; Rocha, M. F. G.; J. Appl. Microbiol. 2008, 104, 1383.

11. Rosa, M. S. S.; Mendonça-Filho, R. R.; Bizzo, H. R.; Rodrigues, I. A.; Soares, R. M. A.; Souto-Padrón, T.; Alviano, C. S.; Lopes, A. H. C. S.; Antimicrob. Agents Chemother. 2003, 47, 1895.

12. Franca-Neto, A.; Cardoso-Teixeira, A. C.; Medeiros, T. C.; Quitino-Farias, M. S.; Sampaio, C. M.; Coelho-de-Souza, A. N.; Lahlou, S.; Leal-Cardoso, J. H.; Nat. Prod. Commun. 2012, 7 , 1397.
13. Pereira, A. F.; Morais, S. M.; Melo, L. M.; Leal-Cardoso, J. H.; Freitas, V. J. F.; Rev. Bras. Farmacogn. 2012, 22, 522.

14. Simionatto, E.; Bonani, V. F. L.; Morel, A. F.; Poppi, N. R.; Raposo Jr., J. L.; Stuker, C. Z.; Peruzzo, G. M.; Peres, M. T. L. P.; Hess, S. C.; J. Braz. Chem. Soc. 2007, 18, 879.

15. Dumas, C.; Ouellette, M.; Tovar, J.; Cunningham, M. L.; Fairlamb, A. H.; Tamar, S.; Olivier, M.; Papadopoulou, B.; ЕМВO J. 1997, 16, 2590.

16. Romão, P. R. T.; Tovar, J.; Fonseca, S. G.; Moraes, R. H.; Cruz, A. K.; Hothersall, J. S.; Noronha-Dutra, A. A.; Ferreira, S. H.; Cunha, F. Q.; Braz. J. Med. Biol. Res. 2006, 39, 355.

17. Turcano, L.; Torrente, E.; Missineo, A.; Andreini, M.; Gramiccia, M.; Di Muccio, T.; Genovese, I.; Fiorillo, A.; Harper, S.; Bresciani, A.; Colotti, G.; Ilari, A.; PLoS Neglected Trop. Dis. 2018, 12, e0006969.

18. Craveiro, A. A.; Matos, F. J. A.; Alencar, J. W.; J. Chem. Educ. 1976, 53, 652.

19. Adams, R. P.; Identification of Essential Oil Components by Gas Chromatography/Mass Spectrometry, $4^{\text {th }}$ ed.; Allured Publishing Corporation: Carol Stream, IL, USA, 2007.

20. Yepez, B.; Espinosa, M.; Lopez, S.; Bolanos, G.; Fluid Phase Equilib. 2002, 254, 879.

21. Rondon, F. C.; Bevilaqua, C. M. L.; Accioly, M. P.; Morais, S. M.; Andrade-Junior, H. F.; Machado, L. K.; Cardoso, R. P.; Almeida, C. A.; Queiroz-Junior, E. M.; Rodrigues, A. C.; Vet. Parasitol. 2011, 178, 235.

22. Tempone, A. G.; Borborema, S. E. T.; Andrade, H. F.; Gualda, N. C. A.; Yogi, A.; Carvalho, C. S.; Bachiega, D.; Lupo, F. N.; Bonotto, S. V.; Fischer, D. C. H.; Phytomedicine 2005, 12, 382.

23. Peter, A.; Kollman, P. K.; Weiner, A. D.; Biopolymers 1981, 20 , 2583.

24. Morris, G. M.; Huey, R.; Lindstrom, W.; Sanner, M. F.; Belew, R. K.; Goodsell, D. S.; Olson, A. J.; J. Comput. Chem. 2009, 30,2785 .

25. Hunter, A. D.; J. Chem. Educ. 1997, 74, 905.

26. Gasteiger, J.; Marsili, M.; Tetrahedron 1980, 36, 3219.

27. Mashhadi, H. R.; Shanechi, H. M.; Lucas, C.; IEEE Trans. Power Syst. 2003, 18, 1181.

28. Halgren, T. A.; Murphy, R. B.; Friesner, R. A.; Beard, H. S.; Frye, L. L.; Pollard, W. T.; Banks, J. L.; J. Med. Chem. 2004, 47, 1750 .

29. Kitchen, D. B.; Decornez, H.; Furr, J. R.; Bajorath, J.; Nat. Rev. Drug Discovery 2004, 3, 935.

30. Discovery Studio 1.5; Accelrys Software Inc., USA, 2006.

31. The PyMOL Molecular Graphics System, version 2.0; Schrödinger, LLC, USA, 2017.

32. GraphPad Prism, version 4.00 for Windows; GraphPad Software, San Diego, USA, 2003.

33. Statistical Analysis System-SAS, User's guide; SAS Institute: Cary, NC, USA, 2002, p. 525.

34. Gobbo-Neto, L.; Lopes, N. P.; Quim. Nova 2007, 30, 374. 
35. Morais, S. M.; Braz Filho, R.; Produtos Naturais: Estudos Químicos e Biológicos; Ed. UECE: Fortaleza, Brasil, 2007.

36. Morais, S. M.; Catunda-Júnior, F. E. A.; Silva, A. R. A.; MartinsNeto, J. S.; Quim. Nova 2006, 29, 907.

37. Nascimento, K. F.; Moreira, F. M. F.; Santos, J. A.; Kassuya, C. A. L.; Croda, J. H. R.; Cardoso, C. A. L.; Vieira, M. C.; Ruiz, A. L. T. G.; Foglio, M. A.; Carvalho, J. E.; Formagio, A. S. N.; J. Ethnopharmacol. 2018, 210, 351.

38. Calleja, M. A.; Vieites, J. M.; Montero-Meterdez, T.; Torres, M. I.; Faus, M. J.; Gil, A.; Suarez, A.; Br. J. Nutr. 2013, 109, 394.

39. Caldas, G. F. R.; Oliveira, A. R. S.; Araújo, A. V.; Lafayette, S. S. L.; Albuquerque, G. S.; Silva-Neto, J. C.; Costa-Silva, J. H.; Ferreira, F.; da Costa, J. G. M.; Wanderley, A. G.; PLoS One 2015, 10, e0134558.

40. Alkathiri, B.; El-Khadragy, M. F.; Metwally, D. M.; Al-Olayan, E. M.; Bakhrebah, M. A.; Moneim, A. E.; Int. J. Environ. Res. Public Health 2017, 14, 1592.

41. Soares, D. C.; Portella, N. A.; Ramos, M. F.; Siani, A. C.; Saraiva, E. M.; J. Evidence-Based Complementary Altern. Med. 2013, 2013, 761323.
42. Wang, Z.; Tabakoff, B.; Levinson, S. R.; Heinbockel, T.; Acta Pharmacol. Sin. 2015, 36, 791.

43. Lima, C. C.; Criddle, D. N.; Coelho-de-Souza, A. N.; Monte, F. J. Q.; Jaffar, M.; Leal-Cardoso, J. H.; Planta Med. 2000, 66, 408.

44. Vila-Nova, N. S.; Morais, S. M.; Falcão, M. J. C.; Alcantara, T. T. N.; Ferreira, P. A. T.; Cavalcanti, E. S. B.; Vieira, I. G. P.; Campello, C. C.; Wilson, M.; Exp. Parasitol. 2013, 133, 334.

45. Monzote, L.; Geroldinger, G.; Tonner, M.; Scull, R.; de Sarkar, S.; Bergmann, S.; Bacher, M.; Staniek, K.; Chatterjee, M.; Rosenau, T.; Gille, L.; Phytother. Res. 2018, 32, 1729.

46. Ziaei, A.; Ramezani, M.; Wright, L.; Paetz, C.; Schneider, B.; Amirghofran, Z.; Phytother. Res. 2011, 25, 557.

47. Brown, S. K.; Garver, W. S.; Orlando, R. A.; J. Biomol. Res. Ther. 2017, 6, 154.

48. Pahal, V.; Devi, U.; Singh, M.; Agnihotri, S.; Kaur, P.; Dadhich, K. S.; MOJ Drug Des. Dev. Ther. 2018, 2, 67.

Submitted: January 31, 2019

Published online: July 11, 2019 